University of Montana

ScholarWorks at University of Montana

$1-2001$

\title{
Behavioral Interactions Between Coexisting Species: Song Playback Experiments with Wood Warblers
}

P. R. Martin

Thomas E. Martin

University of Montana - Missoula, tom.martin@umontana.edu

Follow this and additional works at: https://scholarworks.umt.edu/wildbio_pubs

Part of the Life Sciences Commons

Let us know how access to this document benefits you.

\section{Recommended Citation}

Martin, P. R. and Martin, Thomas E., "Behavioral Interactions Between Coexisting Species: Song Playback Experiments with Wood Warblers" (2001). Wildlife Biology Faculty Publications. 18.

https://scholarworks.umt.edu/wildbio_pubs/18

This Article is brought to you for free and open access by the Wildlife Biology at ScholarWorks at University of Montana. It has been accepted for inclusion in Wildlife Biology Faculty Publications by an authorized administrator of ScholarWorks at University of Montana. For more information, please contact scholarworks@mso.umt.edu. 


\title{
BEHAVIORAL INTERACTIONS BETWEEN COEXISTING SPECIES: SONG PLAYBACK EXPERIMENTS WITH WOOD WARBLERS
}

\author{
Paul R. Martin ${ }^{1}$ And Thomas E. MARTin ${ }^{2}$ \\ ${ }^{1}$ Montana Cooperative Wildife Research Unit, Avian Studies Program, University of Montana, \\ Missoula, Montana 59812 USA \\ ${ }^{2}$ United States Geological Survey, Biological Resources Division, Montana Cooperative Wildlife Research Unit, \\ Avian Studies Program, University of Montana, Missoula, Montana 59812 USA
}

\begin{abstract}
Behavioral interactions between coexisting species may reflect underlying ecological interactions or may arise from factors unrelated to ecological interactions between species. We examined behavioral interactions between two coexisting, migratory wood warblers that competitively interact on breeding territories in central Arizona, USA. The larger Orange-crowned Warbler (Vermivora celata) is aggressive toward the later-arriving Virginia's Warbler (V. virginiae) and responds to playback of Virginia's Warbler songs by approaching the playback speaker or by singing over Virginia's Warbler songs. Virginia's Warblers retreat from interactions with Orange-crowned Warblers and avoid the playback speaker when presented with Orange-crowned Warbler songs. Responses of both species to song playback of the opposite species differed from responses to conspecific songs, indicating that behavioral interactions do not result from misdirected intraspecific aggression. Behavioral responses were consistent with observed ecological interactions between the two species and suggest that asymmetrical behavioral aggression by the dominant Orange-crowned Warbler may be an important mechanism for competitive interactions involving nest sites. These results support previous studies that have used behavioral experiments to infer ecological interactions among coexisting species. While Orange-crowned Warblers may benefit from aggressively excluding Virginia's Warblers from preferred nest sites, limited data on Virginia's Warbler settlement patterns suggest that Virginia's Warblers do not avoid settling on Orange-crowned Warbler territories. Similar reproductive success in sympatric vs. allopatric habitats suggests little consequence for Virginia's Warblers settling with Orange-crowned Warblers, despite increased reproductive success of Virginia's Warblers in sympatric habitat when Orange-crowned Warblers were experimentally removed.

Key words: behavioral dominance; behavioral interactions, habitat selection; indirect interactions; mate attraction; song playback; species interactions, Vermivora celata, Vermivora virginiae, wood warblers.
\end{abstract}

\section{INTRODUCTION}

Behavioral interactions among coexisting species have repeatedly been used to infer the presence of underlying ecological interactions (e.g., Heller 1971, Catchpole 1977, 1978, Rice 1978, Reed 1982, Catchpole and Leisler 1986, Prescott 1987, Robinson and Terborgh 1995, Martin et al. 1996). Whether such behavioral interactions accurately reflect ecological interactions, however, is unclear. For example, Murray $(1971,1976,1981)$ suggested that some interactions among species may result from misdirected intraspecific aggression, and thus may not be directly related to ecological interactions among species. Alternatively, behavioral interactions may be an important component of ecological interactions, such as in the case of interference competition (Elton and Miller 1954, Park 1954, Miller 1969, Morse 1974).

Orange-crowned (Vermivora celata) and Virginia's

Manuscript received 1 October 1999; revised 14 January 2000; accepted 21 January 2000.
(V. virginiae) Warblers provide a unique opportunity to compare behavioral interactions with known ecological and fitness consequences of coexistence for two members of a local guild. Coexistence of Orangecrowned and Virginia's Warblers in central Arizona, USA, results in fitness costs for individuals of both species compared with individuals that bred on plots where the opposite species was experimentally removed (Martin and Martin 2001). Fitness costs for both species resulted from density-dependent increases in nest predation, while Virginia's Warblers experienced additional costs of coexistence with Orange-crowned Warblers through reduced access to nest sites and food (Martin and Martin 2001).

In this paper, we describe behavioral interactions between Orange-crowned and Virginia's Warblers in central Arizona using combined data from observations of natural interactions, reciprocal song playback experiments, and observations of settlement patterns of the later-arriving, smaller Virginia's Warbler. We used these data to address three questions: (1) How do 
Orange-crowned and Virginia's Warblers behave toward the opposite species? (2) Do responses to heterospecifics differ from responses to conspecifics? (3) Do behavioral responses to heterospecifics reflect ecological interactions among species? The first question addresses the details of how Orange-crowned and Virginia's Warblers behaviorally interact. The second question addresses the hypothesis of Murray (1971, 1976, 1981), that behaviors directed toward heterospecifics may result from misdirected intraspecific behaviors. The third question incorporates data on ecological and fitness consequences of coexistence for Orange-crowned and Virginia's Warblers (from Martin and Martin 2001), and allows us to interpret whether behavioral interactions are indeed related to or important in ecological interactions between the two species, providing a more inclusive perspective of how these two species coexist.

\section{Study Area And Methods}

\section{Study area}

We studied Orange-crowned and Virginia's Warblers on snowmelt drainages located on the Mogollon Rim in central Arizona, USA $\left(34^{\circ} 25^{\prime} \mathrm{N} ; 111^{\circ} 10^{\prime} \mathrm{W}\right)$ at $\sim 2300 \mathrm{~m}$ elevation. The forest is comprised of quaking aspen (Populus tremuloides), Douglas-fir (Pseudotsuga menziesii), white fir (Abies concolor), ponderosa pine (Pinus ponderosa), southwestern white pine (Pinus strobiformis), and Gambel oak (Quercus gambellii). Understory vegetation was comprised primarily of canyon maple (Acer grandidentatum), New Mexican locust (Robinia neomexicana), saplings of overstory tree species, golden pea (Thermopsis pinetorum), raspberry (Rubus strigosus), and various grasses. Overall, the distribution of plant species varied across the width of the snowmelt drainages, with pine, oak, and locust dominating the upper slopes, and aspen and maple dominating the bottom of the drains (Martin 1998). Forest surrounding the snowmelt drainages differs markedly from forest within the drainages, and is characterized by open ponderosa pine with locust and oak in the subcanopy and little understory vegetation (Martin 1998). For more details on the study site and forest bird community, see Martin (1988, 1993, 1998, Martin and Martin 2001).

\section{Study species}

Orange-crowned and Virginia's Warblers are ecologically similar, closely related oscine passerines in the family Parulidae. Both species nest on the ground, usually at the base of small trees. Both species are predominately insectivorous on their breeding grounds, obtaining insects and other arthropods primarily by gleaning from foliage or by probing into leaf buds. In addition, both species share the same adult and nest predators (see Martin and Martin 2001). Orangecrowned Warblers are heavier than Virginia's (9.0 g vs.
7.8 g, respectively; Dunning 1993), and dominate in aggressive interactions between the two species. Orange-crowned Warblers arrive at the study sites in Arizona earlier on average than Virginia's Warblers, and commence nesting earlier in the season (Martin and Martin 2001: Fig. 2). Both species, however, significantly overlap in their nesting, both temporally and spatially, and completely overlap breeding territories on our study sites (Martin and Martin 2001: Fig. 2; Martin 1998). See Martin (1998) and Martin and Martin (2001) for more detailed accounts of these two species.

\section{Natural interactions}

Natural interactions between Orange-crowned and Virginia's Warblers were recorded during the course of field work in 1995, 1996, 1997, and 1998. Details of the interactions recorded included the role of each species in the interaction (e.g., which species was the aggressor in an aggressive interaction), and the behaviors of each individual (e.g., male Orange-crowned Warbler supplanted male Virginia's Warbler). Interactions were only recorded from plots where both Orange-crowned and Virginia's Warblers were present; however, any interactions involving at least one Vermivora were recorded (excluding interactions with known avian predators). In 1995, observations were made during $\sim 135$ $\mathrm{h}$ in areas where both species occurred. In 1996-1998, P. R. Martin spent the majority of time on experimental removal plots (see Martin and Martin 2001), and thus observation time was limited. Throughout the period, observations were made during the course of other work, and numbers of interactions may not reflect accurate rates of interactions between the two species. Nonetheless, observations of natural interactions provide an important context for song playback experiments and for understanding relationships between Orange-crowned and Virginia's Warblers in nature.

\section{Experimental song playback}

Playback setup.-Song playback experiments and the methods below follow Martin et al. (1996), except that conspecific stimuli were always broadcast last (Table 1). Song playback experiments were performed on 18 territorial male Orange-crowned Warblers from 610 May $1997(N=12)$, and from 15-17 June 1998 ( $N$ $=6)$, and on 18 territorial male Virginia's Warblers from 6-14 May $1997(N=12)$, and from 19 May to 20 June $1998(N=6)$. Playback experiments were performed in the morning (0600-1200 MST), in all weather conditions judged not to affect the response of the birds or the ability of the observer to follow the birds (e.g., in high winds or heavy rains).

Each playback experiment lasted $11 \mathrm{~min}$, during which three song stimuli were broadcast (see Table 1). This repeated-measures design was used to control for intersubject variation because each focal bird received all stimuli within an eleven minute period (see Martin et al. 1996). Song stimuli were presented to focal ter- 
TABLE 1. Design of repeated-measures song playback experiments presented to 18 territorial male Orange-crowned Warblers and 18 territorial male Virginia's Warblers.

\begin{tabular}{lcc}
\hline \hline \multicolumn{1}{c}{ Stimulus } & $\begin{array}{c}\text { Duration } \\
\text { (min) }\end{array}$ & $\begin{array}{c}\text { Behavioral } \\
\text { observations } \\
\text { collected }\end{array}$ \\
\hline No stimulus ("prestimulus") & 1 & yes \\
Stimulus 1 (either control or experimental stimulus) & 1 & yes \\
No stimulus ("poststimulus 1") & 1 & yes \\
No stimulus (break) & 2 & no \\
Stimulus 2 (either experimental or control stimulus) & 1 & yes \\
No stimulus ("poststimulus 2") & 1 & yes \\
No stimulus (break) & 2 & no \\
Conspecific song stimulus & 1 & yes \\
No stimulus ("poststimulus conspecific") & 1 & yes \\
\hline
\end{tabular}

Note: Playback stimuli consisted of songs of Orange-crowned Warblers, Virginia's Warblers, and Green-tailed Towhees (the control).

ritorial males at fixed volumes from within their territories. A 3-min period with no stimulus before the second and third stimuli controlled for carryover in response from the previous song stimuli (see Table 1). During pilot trials in 1995 and 1996, we found that a 3-min break provided sufficient time for both Orangecrowned and Virginia's Warblers to calm down after conspecific song stimulus (i.e., there was a decrease in behaviors characteristic of response to conspecific songs, such as flights toward speaker and song rate). To further ensure that a 3-min break was adequate, we tested for effects of song stimulus order, which would be expected if behaviors in response to one stimulus carried over into the next. We expected response to conspecific song stimulus to be strongest and thus provide the greatest potential for carryover in response to subsequent stimuli. Thus, we played conspecific song stimulus last in all experiments (see Table 1; cf. Martin et al. 1996). Occasionally, song stimulus would attract individuals other than the focal bird. In these cases, we could not distinguish whether the focal bird was responding to our song stimulus or to the presence of another responding individual, so these data were not used in the analysis.

Singing male Orange-crowned and Virginia's Warblers that defended territories that permitted continuous observations (e.g., smaller territories away from steep canyons) were chosen preferentially for playback experiments, although within this group we selected males at random. For each territorial male, we placed a speaker (SME-AFS Field Speaker, Saul Mineroff Electronics, Elmont, New York, USA) and playback recorder (Sony TCM-5000 high frequency tape recorder, Saul Mineroff Electronics) within its territory, 1-3 $\mathrm{m}$ above the ground. One observer recorded all of the movements, vocalizations, and estimated locations of the focal male relative to the speaker using a tape recorder in 1997 , or directly onto paper in 1998 . The observer for half of the experiments in 1997 was C. A. Morton, while the observer for the other half was P. R. Martin. The observer for all experiments in 1998 was P. R. Martin. For all experiments, flagging tape was placed on two sides of the playback speaker at a distance of $5 \mathrm{~m}$ and $10 \mathrm{~m}$ to assist in distance estimation. In all cases the observer estimated distance and heights to the nearest meter. Behavioral data were gathered and analyzed for seven 1-min intervals during the playback experiment (see Table 1).

Song stimuli.-The three song stimuli consisted of songs of Orange-crowned Warbler, Virginia's Warbler, and Green-tailed Towhee (Pipilo chlorurus; control), recorded from the study area in 1996. Multiple replicates (multiple songs from three different individuals of each species) were used to obviate concerns regarding the external validity of playback experiments (i.e., to provide an appropriate representation of each species' songs; see Kroodsma 1989). To make a playback tape, one minute of natural song from one of the three different individuals recorded for each species was selected at random and recorded onto a playback tape. Songs were recorded from distances of $<10 \mathrm{~m}$ using a ME-66 short shotgun microphone, SME-BA3 pre-amplifier, and a Sony TCM-5000 high frequency tape recorder (all from Saul Mineroff Electronics). To create playback tapes, periods between songs were cut, and sound levels for songs were set as equal across species and tapes. Playback tapes reflected natural song rates from 1-min recordings of focal individuals (5-6 songs/min for Orange-crowned and Virginia's Warblers and 6-8 songs/min for Green-tailed Towhee). We used six playback tapes representing the different recordings from three individuals for each species in two potential orders of song stimuli (either control stimulus first, or experimental stimulus first; see Table 1). Thus, each of the three recordings for control and experimental stimuli was played twice (once as the first stimulus, and once as the second stimulus; conspecific stimulus always came third) for a total of six playback tapes. The selection of playback tapes was block randomized; each of the six playback tapes was played to three different focal individuals, for a total of 18 experiments for each species.

Green-tailed Towhee song was used as a control in the experiment to compare response of Orange- 
crowned and Virginia's Warblers to song of another common forest passerine in the area. Green-tailed Towhee territories regularly overlap both Orangecrowned and Virginia's Warbler territories on our study sites in Arizona (P. R. Martin and T. E. Martin, unpublished data). Green-tailed Towhee foraging and nesting behavior, however, differs markedly from Orange-crowned and Virginia's Warblers (Dobbs et al. 1998, Martin 1998), and no interactions between Green-tailed Towhees and the focal warbler species have been recorded on our study sites (P. R. Martin and T. E. Martin, unpublished data). These ecological differences, lack of interactions, and different song morphology (cf. Dobbs et al. 1998) make Green-tailed Towhees an ideal control species for song playback experiments on both Orange-crowned and Virginia's Warblers.

Variables and statistical analysis.-Recordings of observations of focal males during playback experiments were transcribed for 5-s intervals in 1997, and summarized from field notes in 1998. Five variables were then calculated from each transcribed playback (Table 2). Variables were selected because they characterize a behavioral response to vocal stimuli in other closely related species (cf. Martin et al. 1996, Fotheringham et al. 1997). Values for five variables were recorded for seven 1-min intervals (see Table 1). For one variable, songs that overlapped stimuli, values could be recorded only for intervals during which song stimuli were presented. Thus, overlapping songs were only recorded for the three song stimulus intervals (see Table 1).

To address the first question, we examined the first five playback intervals that included only responses to control and heterospecific songs. Within these intervals, some behavioral variables were highly intercorrelated. Thus, we collapsed significantly correlated variables into composite variables using Principal Components Analysis (correlation matrix; no rotations). For Orange-crowned Warblers, minimum distance to playback speaker, number of flights, and latency to flight toward speaker were all significantly correlated with each other $(P<0.05$ for all pairwise comparisons $)$. Thus, these variables were combined into one composite variable (eigenvalue $=1.55,52 \%$ variance explained), with the following factor loadings: minimum distance to speaker (0.78), number of flights $(-0.61)$, and latency to flight toward speaker (0.75). Similarly, for Virginia's Warbler, number of flights and latency to flight toward speaker were significantly correlated $(P<0.05)$, and consequently were combined into one composite variable (eigenvalue $=1.56,78 \%$ variance explained), with the following factor loadings: number of flights (0.88), and latency to flight toward speaker $(-0.88)$. These composite variables were used in subsequent analyses in place of the original variables.

We analyzed behavioral variables using a series of block-design (on individual) type III ANOVAs. Indi-
TABLE 2. Behavioral variables used to measure response of territorial male Orange-crowned and Virginia's Warblers to song playback ( $N=18$ for each species).

\begin{tabular}{|c|c|}
\hline Variable & Description \\
\hline $\begin{array}{l}\text { Minimum distance } \\
\text { to playback } \\
\text { speaker }(\mathrm{m})\end{array}$ & $\begin{array}{l}\text { Minimum distance of the focal bird } \\
\text { to the playback speaker during } \\
\text { the } 1 \text {-min interval }\end{array}$ \\
\hline Number of flights & $\begin{array}{l}\text { Total number of flights }>1 \mathrm{~m} \text { made } \\
\text { by the focal bird during the } 1 \text { - } \\
\text { min interval }\end{array}$ \\
\hline $\begin{array}{l}\text { Latency to flight } \\
\text { toward speaker } \\
\text { (s) }\end{array}$ & $\begin{array}{l}\text { Time until the focal bird flew to- } \\
\text { ward the playback speaker, re- } \\
\text { corded to nearest } 5 \mathrm{~s}\end{array}$ \\
\hline Number of songs & $\begin{array}{l}\text { Total number of songs sung by the } \\
\text { focal bird during the } 1 \text {-min inter- } \\
\text { val }\end{array}$ \\
\hline $\begin{array}{l}\text { Number of songs } \\
\text { overlapping play- } \\
\text { back stimulus }\end{array}$ & $\begin{array}{l}\text { Total number of songs sung by the } \\
\text { focal bird that overlapped the } \\
\text { song stimulus; values were ad- } \\
\text { justed for the proportion of the 1- } \\
\text { min stimulus interval during } \\
\text { which song was broadcast }\end{array}$ \\
\hline
\end{tabular}

vidual and treatment were entered as fixed factors (following SPSS 1997). The effects of order were examined by including it as a covariate in each model, and then testing the effect of order and order $\times$ treatment interaction. Neither order, nor order $\times$ treatment effects were significant in any of the ANOVA models $(P>$ 0.10 for all tests), and thus they were dropped from the models, and the ANOVAs were run a second time without order as a covariate. In the final models (reported in Tables 3 and 4), individual and treatment were entered simultaneously as fixed factors without covariates. The series of ANOVAs (three for Orangecrowned Warbler, four for Virginia's Warbler) tested for differences among the five playback intervals (Table 1; excluding conspecific intervals) for each behavioral variable. In cases where ANOVAs were significant following a sequential Bonferroni correction (Hochberg 1988) for multiple comparisons (three and four comparisons for Orange-crowned and Virginia's Warblers, respectively), Tukey's post hoc tests tested for pairwise differences between the five playback intervals of interest.

To address the second question, we examined the last four playback intervals that included only responses to conspecific and heterospecific songs. Within these intervals, some behavioral variables were highly intercorrelated. Thus, we collapsed significantly correlated variables into composite variables using principal components analysis (correlation matrix; no rotations). For both Orange-crowned and Virginia's Warblers, minimum distance to playback speaker, number of flights, and latency to flight toward speaker were all significantly correlated with each other $(P<0.05$ for all pairwise comparisons within species). Thus, these variables were combined into one composite variable (eigenvalues $=2.04,2.06,68 \%, 69 \%$ variance explained for Orange-crowned and Virginia's Warblers, 
TABLE 3. Results of ANOVAs performed on behavioral data gathered from playback experiments involving 18 territorial male Orange-crowned Warblers.

\begin{tabular}{|c|c|c|c|c|}
\hline Source & MS & df & $F$ & $P$ \\
\hline \multicolumn{5}{|c|}{ A) How do Orange-crowned Warblers respond to Virginia's } \\
\hline \multicolumn{5}{|c|}{ Warbler song? $\dagger$} \\
\hline \multicolumn{5}{|c|}{ Approach to speaker } \\
\hline Individual & 1.6 & 17 & 2.3 & 0.009 \\
\hline Treatment & 3.6 & 4 & 5.1 & $0.001 *$ \\
\hline Error & 0.7 & 68 & & \\
\hline \multicolumn{5}{|c|}{ Number of songs } \\
\hline Individual & 6.4 & 17 & 6.0 & $<0.0001$ \\
\hline Treatment & 1.1 & 4 & 1.0 & 0.40 \\
\hline Error & 1.1 & 68 & & \\
\hline \multicolumn{5}{|c|}{ Number of songs overlapping playback stimulus } \\
\hline Individual & 0.9 & 17 & 1.5 & 0.20 \\
\hline Treatment & 5.5 & 1 & 9.0 & $0.008 *$ \\
\hline Error & 0.6 & 17 & & \\
\hline \multicolumn{5}{|c|}{$\begin{array}{l}\text { B) Does response to Virginia's Warbler song differ from re- } \\
\text { sponse to conspecific song? } \$\end{array}$} \\
\hline \multicolumn{5}{|c|}{ Approach to speaker $\$$} \\
\hline Individual & 1.0 & 17 & 1.7 & 0.08 \\
\hline Treatment & 8.6 & 3 & 15.1 & $<0.0001$ \\
\hline Error & 0.6 & 51 & & \\
\hline \multicolumn{5}{|c|}{ Number of songs } \\
\hline Individual & 4.7 & 17 & 3.2 & 0.001 \\
\hline Treatment & 2.9 & 3 & 1.9 & 0.13 \\
\hline Error & 1.5 & 51 & & \\
\hline \multicolumn{5}{|c|}{ Number of songs overlapping playback stimulus } \\
\hline Individual & 0.8 & 17 & 1.0 & 0.49 \\
\hline Treatment & 5.1 & 1 & 6.3 & $0.023 *$ \\
\hline Error & 0.6 & 17 & & \\
\hline
\end{tabular}

$\dagger$ To address this question, ANOVAs tested for differences between five playback intervals: prestimulus (the first minute of playback before any stimulus), one minute of Green-tailed Towhee (control) song, one minute immediately following Green-tailed Towhee (control) song, one minute of Virginia's Warbler (experimental) song, and one minute immediately following Virginia's Warbler (experimental) song.

$\ddagger$ Represents composite variables of minimum distance to playback speaker, number of flights, and latency to flight toward speaker, created using principal components analysis.

$\S$ To address this question, ANOVAs tested for differences between four playback intervals: one minute of Virginia's Warbler (experimental) song, one minute immediately following Virginia's Warbler (experimental) song, one minute of Orange-crowned Warbler (conspecific) song, and one minute immediately following Orange-crowned Warbler (conspecific) song.

$* P<0.05$ after sequential Bonferroni correction for multiple comparisons (Hochberg 1988; see Methods).

respectively), with the following factor loadings: minimum distance to speaker $(0.78,0.76)$, number of flights $(-0.82,-0.88)$, and latency to flight toward speaker $(0.87,0.85)$ for Orange-crowned and Virginia's Warblers, respectively. These composite variables were used in subsequent analyses in place of the original variables.

We analyzed behavioral variables using the same block-design (on individual) type III ANOVAs described above. The series of ANOVAs (three for Orange-crowned Warbler, three for Virginia's Warbler) tested for differences among the four playback intervals (Table 1; excluding control intervals) for each behavioral variable. In cases where ANOVAs were sig-
TABLE 4. Results of ANOVAs performed on behavioral data gathered from playback experiments involving 18 territorial male Virginia's Warblers.

\begin{tabular}{|c|c|c|c|c|}
\hline Source & MS & df & $F$ & $P$ \\
\hline \multirow{2}{*}{\multicolumn{5}{|c|}{$\begin{array}{l}\text { A) How do Virginia's Warblers respond to Orange-crowned } \\
\text { Warbler song? }\end{array}$}} \\
\hline & & & & \\
\hline \multicolumn{5}{|c|}{ Minimum distance to playback speaker } \\
\hline Individual & 506.9 & 17 & 12.5 & $<0.0001$ \\
\hline Treatment & 84.1 & 4 & 2.1 & 0.09 \\
\hline Error & 40.5 & 68 & & \\
\hline \multicolumn{5}{|l|}{ Flights } \\
\hline Individual & 2.0 & 17 & 2.6 & 0.003 \\
\hline Treatment & 0.8 & 4 & 1.1 & 0.37 \\
\hline Error & 0.8 & 68 & & \\
\hline \multicolumn{5}{|c|}{ Number of songs } \\
\hline Individual & 4.3 & 17 & 7.4 & $<0.0001$ \\
\hline Treatment & 0.6 & 4 & 1.0 & 0.39 \\
\hline Error & 0.6 & 68 & & \\
\hline \multicolumn{5}{|c|}{ Number of songs overlapping playback stimulus } \\
\hline Individual & 0.5 & 17 & 1.0 & 0.49 \\
\hline Treatment & 0.3 & 1 & 0.7 & 0.41 \\
\hline Error & 0.5 & 17 & & \\
\hline
\end{tabular}

B) Does response to Orange-crowned Warbler song differ from response to conspecific song?

\begin{tabular}{|c|c|c|c|c|}
\hline \multicolumn{5}{|c|}{ Approach to speaker\| } \\
\hline Individual & 1.5 & 17 & 2.7 & 0.003 \\
\hline Treatment & 5.9 & 3 & 10.8 & $<0.0001$ \\
\hline Error & 0.5 & 51 & & \\
\hline \multicolumn{5}{|c|}{ Number of songs } \\
\hline Individual & 4.2 & 17 & 2.4 & 0.008 \\
\hline Treatment & 1.7 & 3 & 1.0 & 0.41 \\
\hline Error & 1.7 & 51 & & \\
\hline \multicolumn{5}{|c|}{ Number of songs overlapping playback stimulus } \\
\hline Individual & 1.0 & 17 & 2.7 & 0.03 \\
\hline Treatment & 0.001 & 1 & 0.002 & 0.97 \\
\hline Error & 0.4 & 17 & & \\
\hline
\end{tabular}

$\uparrow$ To address this question, ANOVAs tested for differences between five playback intervals: prestimulus (the first minute of playback before any stimulus), one minute of Green-tailed Towhee (control) song, one minute immediately following Green-tailed Towhee (control) song, one minute of Orangecrowned Warbler (experimental) song, and one minute immediately following Orange-crowned Warbler (experimental) song.

\$ Represents composite variable of number of flights and latency to flight toward speaker, created using principal components analysis.

$\S$ To address this question, ANOVAs tested for differences between four playback intervals: one minute of Orangecrowned Warbler (experimental) song, one minute immediately following Orange-crowned Warbler (experimental) song, one minute of Virginia's Warbler (conspecific) song, and one minute immediately following Virginia's Warbler (conspecific) song.

|| Represents composite variables of minimum distance to playback speaker, number of flights, and latency to flight toward speaker, created using principal components analysis.

$* P<0.05$ after sequential Bonferroni correction for multiple comparisons (Hochberg 1988; see Methods).

nificant following a sequential Bonferroni correction (Hochberg 1988) for multiple comparisons (three comparisons for both Orange-crowned and Virginia's Warblers), Tukey's post hoc tests tested for pairwise differences between the four playback intervals of interest.

Bonferroni corrections were applied to each species separately because data were gathered from indepen- 
dent experiments. Corrections were also applied to the testing of each question separately, following Rice (1989). Within the testing of each question, we used sequential Bonferroni corrections to reduce Type I error because data on multiple behaviors were gathered simultaneously from the same individuals, and significance of any one test would reject the null hypothesis appropriate for each question. While we used the methods of Hochberg (1988), results remain the same (i.e., $P<0.05$ for the same tests) if we use the methods of Rice (1989).

\section{Virginia's Warbler latency experiments}

Results from song playback experiments described above suggested that Virginia's Warblers may avoid the playback speaker when presented with Orangecrowned Warbler song (see Results). The design of the first experiment, however, did not permit us to adequately describe this response because playback intervals lasted only $60 \mathrm{~s}$, and many Virginia's Warblers did not fly toward the speaker during a 60-s interval of prestimulus or control song. Thus, we performed an additional experiment on three territorial male Virginia's Warblers to test the a priori hypothesis that Virginia's Warblers avoid the playback speaker when presented with Orange-crowned Warbler song.

Three territorial male Virginia's Warblers were chosen in the same fashion as the first experiment, and on the same study plots. Playback experiment procedure remained the same as in the first experiment, except that either Orange-crowned Warbler song, or Greentailed Towhee song was broadcast to the focal male continuously until the focal male flew toward the speaker. We then recorded the time (nearest second) from the start of song playback to the first flight toward the playback speaker. Each focal male received both Orange-crowned Warbler and Green-tailed Towhee song treatments, separated by $10 \mathrm{~min}$ in between experiments. Songs were broadcast from the same location within each territory. We observed each focal male for $\sim 10$ min before playback experiments to attempt to place playback speakers near the center of each territory. We alternated the order of stimuli, with Greentailed Towhee (control) song played first for two males, and Orange-crowned Warbler (experimental) song played first for one male. A one-way, paired $t$ test tested the null hypothesis that male Virginia's Warblers did not take longer to fly toward the speaker when presented with Orange-crowned Warbler song as compared with Green-tailed Towhee song.

\section{Virginia's Warbler settlement patterns}

We examined patterns of Virginia's Warbler territory settlement, both within maple drainages where Orangecrowned Warblers occur (sympatric), and between habitats where Orange-crowned Warblers occur (sympatric) and do not occur (allopatric).

Within maple drainages (sympatric).--Orange- crowned Warblers were removed during a study examining the consequences of coexistence for Orangecrowned and Virginia's Warblers on our study plots in central Arizona (Martin and Martin 2001). In 1998, we monitored patterns of male Virginia's Warbler settlement on territories where male Orange-crowned Warblers had settled but were removed, compared with adjacent territories (i.e., 1-2 territories away) where Orange-crowned Warblers had settled but had not been removed. Availability of habitat where Orangecrowned Warblers were present and where Orangecrowned Warblers had been removed varied, but in general there were equal or slightly more territories available where Orange-crowned Warblers had been removed.

Allopatric vs. sympatric habitat.-In the eastern section of our study sites (Ohaco region), pine-oak-locust habitat occurs with and without maple in areas adjacent to each other. In these habitats, we monitored 14 male Virginia's Warbler territories (six with maple and eight without maple) and recorded the sequence of territory settlement by male Virginia's Warblers in 1998. Territories with maple were all settled by Orange-crowned Warblers either before or after male Virginia's Warbler settlement. This comparison allowed us to examine whether Virginia's Warblers preferentially settle in habitat where Orange-crowned Warblers occur (sympatric) or in habitats where Orange-crowned Warblers are naturally absent (allopatric). To provide further insight into settlement patterns, we collected data on reproductive success (number of young fledged per nest) of Virginia's Warblers occurring in pine-oak-locust habitat where Orange-crowned Warblers do not occur (allopatric) from the eastern section of our study sites (Ohaco region, $N=9$ nests; 1998, 1999; 1999 data courtesy of C. Olson), and from similar habitat near Flagstaff, Arizona, $\sim 95 \mathrm{~km}$ northwest of our study sites at $2164 \mathrm{~m}$ in elevation $(N=3$ nests; from Fischer 1978). We compared these data with data on reproductive success of Virginia's Warblers in sympatric maple (snowmelt drainage) habitat where Orangecrowned Warblers were present, and where Orangecrowned Warblers had been experimentally removed (from Martin and Martin 2001).

\section{REsults}

\section{Natural interactions}

A total of 66 interactions involving Vermivora were observed over the course of study, comprising 40 different interacting pairs of birds (excluding interactions with known avian predators). Interactions among Orange-crowned and Virginia's Warblers constituted $65 \%$ of observed interactions involving $68 \%$ of interacting pairs of birds. Additional species interacting with Vermivora were Yellow-rumped Warbler, Dendroica coronata auduboni (10\% of observations); Dark-eyed Junco, Junco hyemalis caniceps (8\%); 
Mountain Chickadee, Parus gambeli gambeli (5\%); and four other species of birds $(<5 \%$ each).

In all interactions among Vermivora, the Orangecrowned Warbler was dominant to and aggressive toward the smaller Virginia's Warbler. In no cases were Virginia's Warblers observed to be the aggressor, and in all cases Virginia's Warblers retreated or avoided attacks by Orange-crowned Warblers. Interactions between the two species involved both sexes, although male-male interactions were most common: male Orange-crowned-male Virginia's (52\% of interactions), male Orange-crowned-female Virginia's (7\%), female Orange-crowned-male Virginia's $(0 \%)$, female Orange-crowned-female Virginia's (7\%), interactions where one or both sexes were not identified (34\%). Interactions between the two species consisted of physical chases through the air (41\% of interactions), supplanting (33\%), and Orange-crowned Warblers singing overtop of Virginia's Warbler's songs $(26 \%)$. The relative importance of these interactions may be skewed because active chases are more obvious than subtle interactions involving song; however, results nonetheless demonstrate that interactions between the two species are diverse. In cases where Orange-crowned Warblers sang overtop of Virginia's Warbler's songs, Orange-crowned Warblers also approached the singing male Virginia's $86 \%$ of the time (to distances of $<1-$ $10 \mathrm{~m}$ ). In addition to these observations, Orangecrowned Warblers of unknown sex were observed aggressively attacking female Virginia's Warblers during nest construction ( $7 \%$ of interactions), with additional observations of Orange-crowned Warblers attacking building female Virginia's Warblers made by other observers at the study site (there was also one case of a Dark-eyed Junco repeatedly attacking a female Orangecrowned Warbler attempting to build a nest $9 \mathrm{~m}$ from an active junco nest). Interactions among Orangecrowned and Virginia's Warblers were most common early in the breeding season. Of all interactions observed between the two species, $81 \%$ occurred in May, $19 \%$ in June, and $0 \%$ in July. Interactions between Orange-crowned and Virginia's Warblers were at times physical, with male Orange-crowned Warblers coming into direct contact with male Virginia's for almost a full second on occasion, and nesting material occasionally being physically knocked out of female Virginia's bills as they attempted to build nests. Most interactions, however, did not involve prolonged physical contact, and no injuries or deaths of Virginia's Warblers resulting from Orange-crowned Warbler aggression were observed.

\section{Playback experiments on Orange-crowned Warblers}

1. Response to Virginia's Warbler song.-Territorial male Orange-crowned Warblers responded to Virginia's Warbler song playback by approaching the playback speaker (Table 3; Fig. 1a), and by overlapping Virginia's Warbler songs with songs of their own (Table
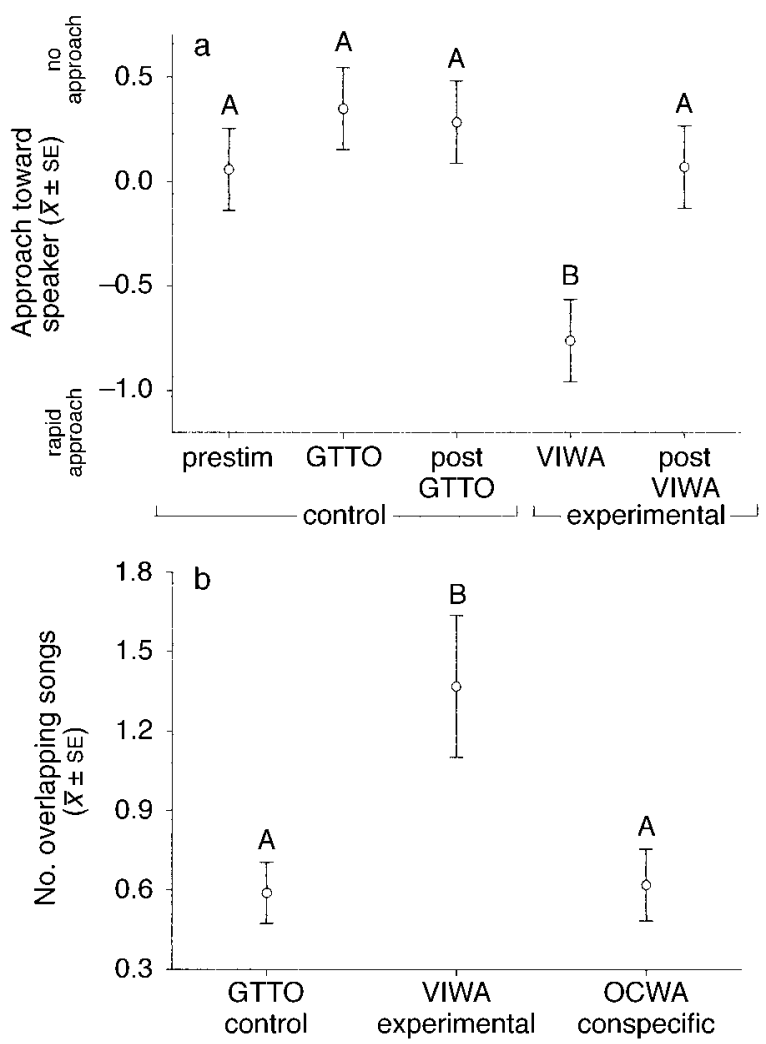

FIG. 1. (a) Approach of territorial male Orange-crowned Warblers to the broadcast speaker (mean $\pm 1 \mathrm{SE}$ ) during control and experimental playback intervals $(N=18$ for all treatment intervals). Values represent a composite variable derived from a principal components analysis on latency to approach toward speaker, minimum distance of approach toward speaker, and number of flights (see Methods). (b) Number of songs sung over playback stimuli (controlling for total duration of song stimuli) (mean $\pm 1 \mathrm{SE}$ ) by territorial male Orange-crowned Warblers during control, experimental, and conspecific playback intervals $(N=18$ for all treatment intervals). See Table 3 for ANOVA results. Values that share the same letter were not statistically different from each other (Tukey's posthoc test, $P \geq 0.05$ ). Figures do not represent order of stimuli (see Table 1). Playback interval abbreviations are: prestim, the first minute of playback before any of the stimuli were presented; GTTO, one minute of Green-tailed Towhee (control) song; post GTTO, the minute immediately following; VIWA, one minute of Virginia's Warbler (experimental) song; post VIWA, the minute immediately following; and OCWA, one minute of Orange-crowned Warbler (conspecific) song.

3; Fig. 1b). These two responses were negatively correlated (Pearson correlation, $r=-0.53$, two-tailed $P=$ $0.024)$, suggesting that these responses are alternative behaviors of territorial male Orange-crowned Warblers in response to singing male Virginia's Warblers on their territories.

2. Response to Virginia's Warbler song compared with conspecific song.-Orange-crowned Warblers approached the playback speaker in response to both Virginia's Warbler song and conspecific song (Table 3). Orange-crowned Warblers, however, approached the 
playback speaker more quickly and closer in response to conspecific song compared with Virginia's Warbler song (Table 3; Tukey's post hoc test, experimental vs. conspecific intervals $P<0.0001)$. Orange-crowned Warbler response to Virginia's Warbler song also differed from response to conspecific song with respect to the number of songs sung overtop of the song stimulus (Table 3; Fig. 1b). Orange-crowned Warblers did not sing overtop of conspecific songs; however, in response to Virginia's Warbler songs, Orange-crowned Warblers sang significantly more songs that overlapped the song stimulus (Table 3; Fig. 1b).

\section{Playback experiments on Virginia's Warblers}

1. Response to Orange-crowned Warbler song.Territorial male Virginia's Warblers did not respond to Orange-crowned Warbler song in any measurable way during the first playback experiment (Table 4). Latency to approach toward speaker data (Fig. 2a), however, suggested that Virginia's Warblers may avoid the playback speaker during Orange-crowned Warbler song playback. Further experiments that tested this hypothesis showed that Virginia's Warblers do avoid the playback speaker when Orange-crowned Warbler song is broadcast (Fig. 2b). Male Virginia's Warblers took almost five times longer to move toward the playback speaker when presented with Orange-crowned Warbler song as compared to Green-tailed Towhee (control) song (Fig. 2b).

2. Response to Orange-crowned Warbler song compared with conspecific song.-Virginia's Warbler response to Orange-crowned Warbler song was opposite to their response to conspecific song (Table 4; Fig. 2a, b; Tukey's post hoc test, experimental vs. conspecific intervals, $P<0.0001)$. Male Virginia's Warblers approached the playback speaker in a median time of 30 $\mathrm{s}$ when presented with conspecific song stimulus (Fig. 2a), however, they avoided the playback speaker when presented with Orange-crowned Warbler songs (Fig. $2 a, b)$.

\section{Virginia's Warbler settlement patterns}

Within maple drainages (sympatric).-Male Virginia's Warblers did not appear to preferentially settle on territories where Orange-crowned Warblers had been removed compared with territories where Orangecrowned Warblers were present. Out of four male Virginia's Warblers that settled, two settled on territories where Orange-crowned Warblers were present instead of settling on adjacent territories where Orangecrowned Warblers had been removed. The other two Virginia's males settled on territories where Orangecrowned Warblers had been experimentally removed, while adjacent territories where Orange-crowned Warblers were present were available. While these sample sizes are small, there was no observed tendency to avoid territories where Orange-crowned Warblers were present.
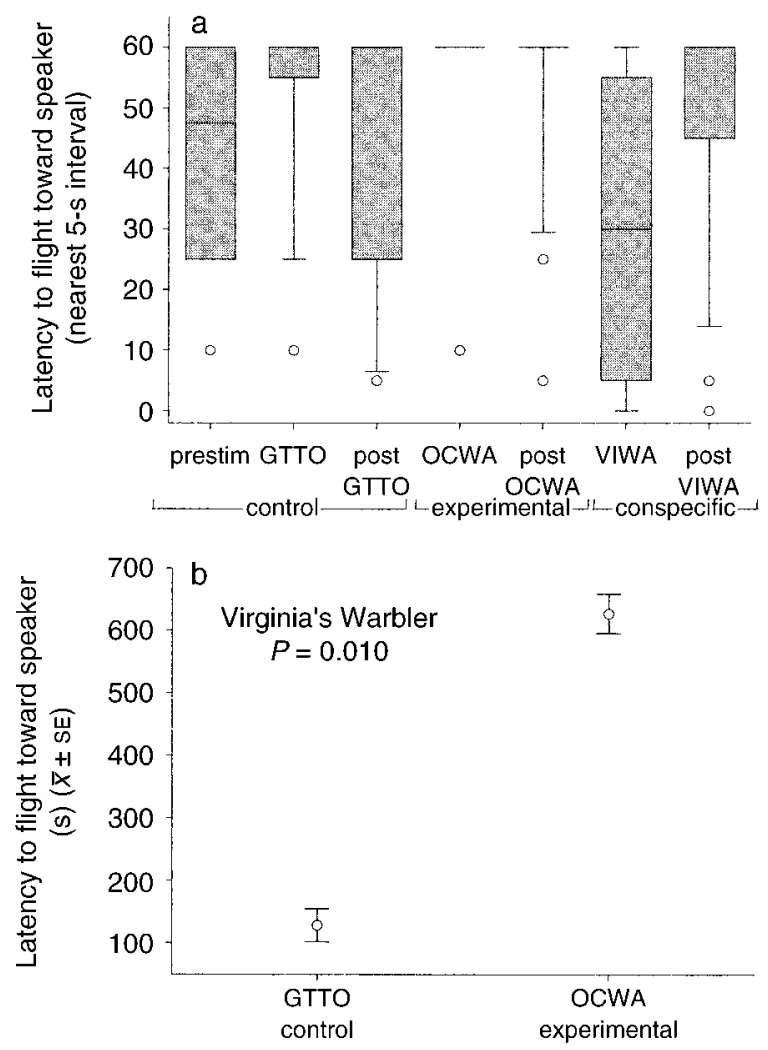

FIG. 2. (a) Latency (nearest 5-s interval) to approach toward speaker of territorial male Virginia's Warblers during control, experimental, and conspecific song playback intervals $(N=18$ for all treatment intervals). Boxplots represent median values (middle line), 25-75 percentiles (box), 10-90 percentiles (bars), and outliers (circles). See Fig. 1 caption for playback interval abbreviations. (b) Latency (nearest second) to approach toward speaker (mean $\pm 1 \mathrm{SE}$ ) of territorial male Virginia's Warblers presented with Green-tailed Towhee (GTTO; control) songs and Orange-crowned Warbler (OCWA; experimental) songs ( $N=3$ for each treatment). Songs were played continuously until the focal individual moved toward the speaker. Figures do not represent order of stimuli (see Table 1, Methods).

Allopatric vs. sympatric habitats.-Virginia's Warblers settled in pine-oak-locust habitat with maple and with Orange-crowned Warblers preferentially to adjacent pine-oak-locust habitat without maple and without Orange-crowned Warblers $(t=6.1, \mathrm{df}=12, P<$ $0.0001)$. Out of fourteen territories settled, the first six Virginia's males settled on territories with maple, while the remaining eight Virginia's males all settled in the habitat without maple. Reproductive success (number of young fledged per nest) of Virginia's Warblers did not appear to differ between allopatric and sympatric habitat (Fig. 3), despite increased reproductive success in sympatric habitat when Orange-crowned Warblers were experimentally removed (Fig. 3; Martin and Martin 2001). 


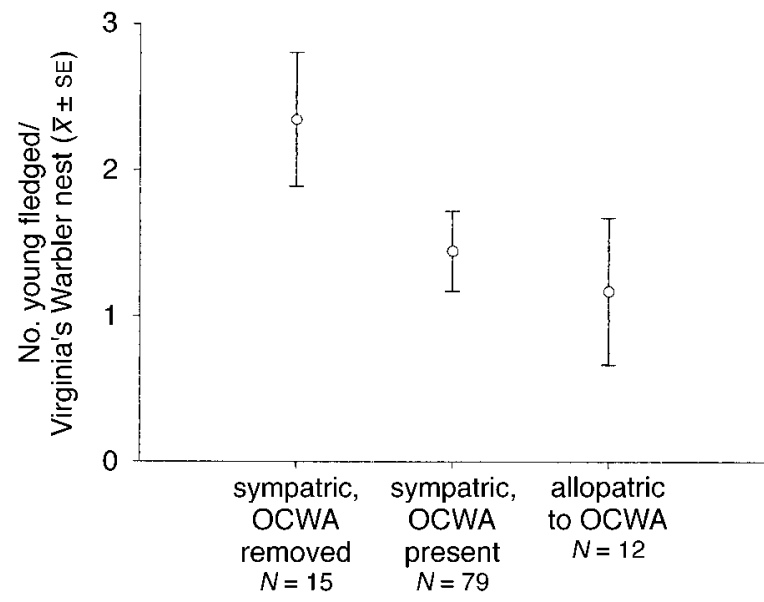

FIG. 3. Number of young fledged per Virginia's Warbler nest (mean $\pm 1 \mathrm{SE}$ ) in maple (i.e., typical snow-melt drainage) habitat, where Orange-crowned Warblers coexist (sympatric) and were either experimentally removed (OCWA removed) or present (OCWA present), compared with nearby pine-locust-oak habitat where Orange-crowned Warblers do not occur (allopatric). Maple habitat with Orange-crowned Warblers and pine-oak-locust habitat without Orange-crowned Warblers are naturally occurring situations. Maple habitat without Orange-crowned Warblers may not typically occur in nature, given that Orange-crowned Warblers saturate suitable maple habitat in most years (mean of 2.3 males per territory; P. R. Martin and T. E. Martin, unpublished data from removal experiments in 1997). Sympatric data are from Martin and Martin 2001 .

\section{DISCUSSION}

A variety of studies have illustrated behavioral interactions among species within local guilds (e.g., Heller 1971, Catchpole 1977, 1978, Rice 1978, Catchpole and Leisler 1986, Reed 1982, Prescott 1987, Robinson and Terborgh 1995, Martin et al. 1996). While these studies often infer ecological interactions (e.g., competition) among species, none have been able to directly compare behavioral interactions with known ecological and fitness consequences of coexistence. Orange-crowned and Virginia's Warblers provide a unique opportunity to compare known costs of coexistence with behavioral interactions between the same species. Observations of natural interactions, song playback experiments, and settlement patterns of the later-arriving Virginia's Warbler illustrate that (1) Orange-crowned Warblers are behaviorally dominant and aggressive toward Virginia's Warblers, while Virginia's Warblers avoid or retreat from interactions with Orange-crowned Warblers, (2) responses to heterospecifics differ from responses to conspecifics for both species and do not reflect misdirected intraspecific behaviors, and (3) behavioral responses to heterospecifics correspond well with observed ecological and fitness consequences of coexistence for the two species.

\section{How do Orange-crowned and Virginia's Warblers interact?}

Natural interactions and song playback experiments illustrate that the larger, earlier settling Orangecrowned Warbler is behaviorally dominant to coexisting Virginia's Warblers. In response to Virginia's Warbler song playback, territorial male Orange-crowned Warblers either approached the playback speaker, or sang overtop of Virginia's Warbler songs (Fig. 1a, b); results that are concordant with observations from nature. Approaching, supplanting, and chasing of Virginia's Warblers by Orange-crowned Warblers appear to be aggressive behaviors that may interfere with Virginia's Warbler nest site choice and other behaviors when the two species overlap territories. Similarly, if song in unpaired male Virginia's Warblers functions to attract mates and defend territories against other conspecific males (as in most temperate oscines; Kroodsma and Byers 1991), then Orange-crowned Warbler overlapping of Virginia's Warbler songs may be an aggressive response to interfere with coexisting Virginia's Warblers. Indeed, preliminary experiments where we overlapped songs of unpaired male Virginia's Warblers with recorded songs of Orange-crowned Warblers for 5-6 h daily resulted in Virginia's Warblers nearly doubling the size of their breeding territories and a 2.5-d delay in male pairing (compared with controls $N=2$, 2; P. R. Martin and T. E. Martin, unpublished data).

Response of the smaller, later arriving Virginia's Warbler to Orange-crowned Warblers varied with the spatial scale examined. Within territories, Virginia's Warblers responded to Orange-crowned Warbler song playback by avoiding the playback speaker (Fig. 2); a response that corresponds well with observations from nature where Virginia's Warblers are subordinate and retreat from any interactions with aggressive Orangecrowned Warblers. Despite avoiding Orange-crowned Warblers within their territories, Virginia's Warblers appear to preferentially settle in Orange-crowned Warbler maple drainage habitat as compared with adjacent pine-oak-locust habitat where Orange-crowned Warblers do not occur. Even within maple drainage habitat, we have no evidence that male Virginia's Warblers avoid settling on Orange-crowned Warbler territories, although small sample sizes may obscure patterns of avoidance. Overall, Virginia's Warblers avoided Orange-crowned Warblers within their territories (song playback experiments) and with respect to nest site choice (Martin and Martin 2001). Virginia's Warblers did not, however, appear to avoid Orange-crowned Warblers at larger spatial scales, such as avoiding different habitat types. This suggests that choice of habitat type by Virginia's Warblers may be influenced by other factors such as habitat quality. Together, habitat quality and costs of coexistence with other community members may then determine the relative benefits of settling 
in different habitat types (Fig. 3; see Fretwell and Lucas 1970).

\section{Do responses to heterospecifics differ from responses to conspecifics?}

Some authors have argued that responses to coexisting heterospecifics may result from misdirected intraspecific aggression, particularly in closely related species (e.g., Murray 1971, 1976, 1981). In the case of Orange-crowned and Virginia's Warblers, responses to the opposite species involved some entirely different behaviors, illustrating that responses are not simply misdirected intraspecific aggression. Song playback experiments revealed that Orange-crowned Warbler response to Virginia's Warbler songs includes singing overtop of the song stimulus-a response uncharacteristic of interactions with conspecifics (Fig. 1b). Similarly, Virginia's Warbler response to Orange-crowned Warbler songs was opposite that of their response to conspecific songs (Fig. 2a, b). Overall, responses of both species differed significantly from responses to conspecific and control songs, and illustrate that responses to the opposite species are to some degree species specific. These results lend support to other studies that reject misdirected intraspecific aggression as the cause of behavioral interactions among other coexisting bird species (e.g., Catchpole and Leisler 1986, Prescott 1987, Martin et al. 1996).

\section{Do behavioral responses to heterospecifics reflect ecological interactions among species?}

An increasing number of studies provide evidence that coexisting bird species may interact through song (e.g., Fall and Szijj 1959, Szijj 1962, Johnson 1963, Gill and Murray 1972, Ferry and Deshaintre 1974, Emlen et al. 1975, Cody and Walter 1976, Catchpole 1977, 1978, Gorton 1977, Rice 1978, Reed 1982, Garcia 1983, Catchpole and Leisler 1986, Prescott 1987, Robinson and Terborgh 1995, Martin et al. 1996; see also Stein 1958). These studies often argue that behavioral interactions are reflecting underlying ecological interactions among the species involved. If song playback experiments accurately reflect ecological interactions among species, then they can be used as an effective and relatively easy tool to estimate the importance of interactions among species, within or among communities. For example, Robinson and Terborgh (1995) provide evidence that a large number of species in Amazonian Peru may partition habitat and other resources through behavioral interactions. If these behavioral interactions accurately reflect dominance hierarchies and the presence of ecological interactions among coexisting species, then results of their experiments suggest that interactions may play a major role in proximately structuring one of the most species-rich communities on earth.

Results from song playback experiments and observations of natural interactions between Orange- crowned and Virginia's Warblers illustrate that behavioral interactions are indeed representative of ecological interactions between these two species, and may form a mechanistic basis for some competitive interactions and patterns of habitat partitioning. For example, removal experiments show that Virginia's Warblers are excluded from preferred nest sites when the two species coexist (Martin and Martin 2001). The behavioral dominance of Orange-crowned Warblers in both natural interactions and song playback experiments, in addition to observations of Orange-crowned Warblers attacking female Virginia's Warblers during nest construction, suggest that Orange-crowned Warbler interference may help to exclude Virginia's Warblers from preferred nest sites. Conversely, Orangecrowned Warblers experienced only indirect costs of coexistence with Virginia's Warblers, mediated by nest predator behavior (Martin and Martin 2001). Consistent with this result, Virginia's Warblers were behaviorally subordinate, and did not directly interfere with the larger Orange-crowned Warbler in observed natural interactions or in song playback experiments. These results not only suggest that behavioral interactions accurately reflect ecological interactions between coexisting Orange-crowned and Virginia's Warblers, but that aggressive interference may be an important, asymmetrical mechanism for competitive interactions between the two species. These results provide support for other studies that have used behavioral interactions to infer ecological interactions among coexisting species.

\section{Do behavioral interactions have fitness consequences?}

If behavioral interactions play a role in ecological interactions among coexisting species, we may expect behaviors to have consequences for fitness. Indeed, available evidence suggests that, in the case of Orangecrowned and Virginia's Warblers, some behaviors directed toward the opposite species may reduce fitness costs of species coexistence. For Orange-crowned Warblers, aggressive interference may help them exclude Virginia's Warblers from nesting in preferred sites in maple, where Orange-crowned Warblers typically nest. Increased ground nest density when coexisting Orangecrowned and Virginia's Warblers both nest in maple appears to result in observed increases in nest predation (Martin 1996). These patterns suggest that Orangecrowned Warbler interference may reduce fitness costs of coexisting with Virginia's Warblers by promoting habitat (maple vs. locust/oak) and spatial (bottom vs. top of snow-melt drainage) segregation of nests.

For the Virginia's Warbler, habitat settlement in response to Orange-crowned Warblers is best understood by examining fitness consequences of settling in different habitats. Virginia's Warblers preferentially settled in maple habitat where Orange-crowned Warblers occur instead of settling in nearby pine-oak-locust 
habitat where Orange-crowned Warblers do not occur, despite costs for Virginia's Warblers coexisting with Orange-crowned Warblers in maple habitat (Martin and Martin 2001). Reproductive success of Virginia's Warblers in maple habitat with Orange-crowned Warblers, however, appears similar to that of pine-oak-locust habitat without Orange-crowned Warblers (Fig. 3), suggesting that Virginia's Warblers are not preferentially choosing poor habitat. The pattern of reproductive success across habitats (Fig. 3) is consistent with models of ideal free habitat selection (Fretwell and Lucas 1970, Petit and Petit 1996), and suggests that costs associated with coexisting Orange-crowned Warblers in maple habitat may be offset by differences in the quality of maple vs. pine-locust-oak habitats, evident in comparisons of Virginia's Warbler reproductive success in both habitats in the absence of Orange-crowned Warblers (Fig. 3).

Overall, preliminary evidence illustrates that some behaviors of Orange-crowned and Virginia's Warblers toward each other may have fitness consequences, and that behavioral interactions are an important component of competitive interactions between these two species. These results suggest that understanding habitat selection and how species coexist will require a detailed understanding of both behavioral and ecological interactions among species in the context of their fitness consequences (see also Martin 1986).

\section{ACKNOWLEDGMENTS}

Thanks to Cameron Ghalambor, John McKay, Heather Mathewson, Chavez del Agua, Elizabeth Leaf, Josh Tewksbury, Alex Badyaev, T. J. Fontaine, Alison Banks, Wes Hochachka, Mathilde Jullien, Courtney Conway, Shannon and Lindy Garner, Wendy Parsons, Paul Allen, John Lloyd, Bruce Di Labio, Christine James, Raleigh and Lois Robertson, Craig Morton, Gail Adams, Janet Martin, and Jean and Larry Martin for help at all stages of this project. Craig Morton, Jake Cseke, and Janet Martin helped immensely with fieldwork. Thanks to Chris Olson for providing unpublished data. Scott Robinson and an anonymous reviewer provided helpful comments to improve the manuscript. Special thanks to PRM's MSc. thesis committee: Joe Ball, Ray Callaway, and Ken Dial for help throughout this project. Thanks to Joe Ball, Vanetta Burton, Pam Tollefson, Virginia Johnston, John Malloy, Allison Perkins, and Jeff Marks at the Montana Cooperative Wildlife Research Unit for support. The Blue Ridge Ranger Station enabled research on the Mogollon Rim, while the Fish and Wildlife Service, Arizona Fish and Game, and The University of Montana provided the appropriate permits. NSF and BBIRD funding to Tom Martin supported this research for three years. This paper was written and revised while PRM was supported by a Bertha Morton Memorial Scholarship and a scholarship from the Natural Sciences and Engineering Research Council of Canada.

\section{Literature Cited}

Catchpole, C. K. 1977. Aggressive responses of male sedge warblers (Acrocephalus schoenobaenus) to playback of species song and sympatric species song, before and after pairing. Animal Behaviour 25:489-496.

Catchpole, C. K. 1978. Interspecific territorialism and competition in Acrocephalus warblers as revealed by playback experiments in areas of sympatry and allopatry. Animal Behaviour 26:1072-1080.
Catchpole, C. K., and B. Leisler. 1986. Interspecific territorialism in reed warblers: a local effect revealed by playback experiments. Animal Behaviour 34:299-300.

Cody, M. L., and H. Walter. 1976. Habitat selection and interspecific interactions among Mediterranean sylviid warblers. Oikos 27:210-238.

Dobbs, R. C., P. R. Martin, and T. E. Martin. 1998. Greentailed Towhee (Pipilo chlorurus). Pages 1-24 in A. Poole and F. Gill, editors. The birds of North America, Number 368. The Academy of Natural Sciences, Philadelphia, Pennsylvania, USA, and The American Ornithologists' Union, Washington, D.C., USA.

Dunning, J. B., Jr. 1993. CRC handbook of avian masses. CRC Press, Boca Raton, Florida, USA.

Elton, C. S., and R. S. Miller. 1954. The ecological survey of animal communities: with a practical system of classifying habitats by structural characters. Journal of Ecology 42:460-496.

Emlen, S. T., J. D. Rising, and W. L. Thompson. 1975. A behavioral and morphological study of sympatry in the Indigo and Lazuli buntings of the Great Plains. Wilson Bulletin 87:145-179.

Falls, J. B., and L. J. Szijj. 1959. Reactions of eastern and western meadowlarks in Ontario to each others' vocalizations. Anatomical Record 134:560.

Ferry, C., and A. Deschaintre. 1974. Le chant, signal interspecifique chez Hippolais icterina et polyglotta. Alauda 42: 289-312.

Fischer, J. M. 1978. A natural history study of the Virginia's Warbler (Vermivora virginiae) in the ponderosa pine community. Thesis, Northern Arizona University, Flagstaff, Arizona, USA.

Fotheringham, J. R., P. R. Martin, and L. Ratcliffe. 1997. Song transmission and auditory perception of distance in wood warblers (Parulinae). Animal Behaviour 53:12711285.

Fretwell, S. D., and H. L. Lucas, Jr. 1970. On territorial behavior and other factors influencing habitat distribution in birds. I. Theoretical development. Acta Biotheoretica 19: $16-36$.

Garcia, E. F. J. 1983. An experimental test of competition for space between Blackcaps Sylvia atricapilla and Garden warblers Sylvia borin in the breeding season. Journal of Animal Ecology 52:795-805.

Gill, F. B., and B. G. Murray, Jr 1972. Discrimination behavior and hybridization of the Blue-winged and Goldenwinged warblers. Evolution 26:282-293.

Gorton, R. E. 1977. Territorial interactions in sympatric Song Sparrow and Bewick's Wren populations. Auk 94:701-708.

Heller, H. C. 1971. Altitudinal zonation of chipmunks (Eutamias): interspecific aggression. Ecology 52:312-319.

Hochberg, Y. 1988. A sharper Bonferroni procedure for multiple tests of significance. Biometrika 74:800-802.

Johnson, N. K. 1963. Biosystematics of sibling species of flycatchers in the Empidonax hammondii-oberholseriwrightii complex. University of California Publications in Zoology 66:79-238.

Kroodsma, D. E. 1989. Suggested experimental designs for song playbacks. Animal Behaviour 37:600-609.

Kroodsma, D. E., and B. E. Byers. 1991. The function(s) of bird song. American Zoologist 31:318-328.

Martin, P. R., J. R. Fotheringham, L. Ratcliffe, and R. J. Robertson. 1996. Response of American redstarts (suborder Passeri) and least flycatchers (suborder Tyranni) to heterospecific playback: the role of song in aggressive interactions and interference competition. Behavioral Ecology and Sociobiology 39:227-235.

Martin, P. R., and T. E. Martin. 2001. Ecological and fitness consequences of species coexistence: a removal experiment with wood warblers. Ecology 82:189-206. 
Martin, T. E. 1986. Competition among breeding birds: on the importance of considering processes at the level of the individual. Current Ornithology 4:181-210.

Martin, T. E. 1988. Habitat and area effects on forest bird assemblages: is nest predation an influence? Ecology 69: 74-84.

Martin, T. E. 1993. Nest predation and nest sites: new perspectives on old patterns. BioScience 43:523-532.

Martin, T. E. 1996. Fitness costs of resource overlap among coexisting bird species. Nature 380:338-340.

Martin, T. E. 1998. Are microhabitat preferences of coexisting species under selection and adaptive? Ecology 79: 656-670.

Miller, R. S. 1969. Competition and species diversity. Brookhaven Symposium in Biology 22:63-70.

Morse, D. H. 1974. Niche breadth as a function of social dominance. American Naturalist 108:818-830.

Murray, B. G., Jr. 1971. The ecological consequences of interspecific territorial behavior in birds. Ecology 52:414423.

Murray, B. G., Jr. 1976. A critique of interspecific territoriality and character convergence. Condor 78:518-525.

Murray, B. G., Jr. 1981. The origins of adaptive interspecific territorialism. Biological Review 56:1-22.

Park, T. 1954. Experimental studies of interspecific competition. II. Temperature, humidity, and competition in two species of Tribolium. Physiological Zoology 27:177-238.
Petit, L. J., and D. R. Petit. 1996. Factors governing habitat selection by Prothonotary Warblers: field tests of the Fretwell-Lucas models. Ecological Monographs 66:367-387.

Prescott, D. R. C. 1987. Territorial responses to song playbacks in allopatric and sympatric populations of Alder (Empidonax alnorum) and Willow (E. trailli) flycatchers. Wilson Bulletin 99:611-619.

Reed, T. M. 1982. Interspecific territoriality in the chaffinch and great tit on islands and the mainland of Scotland: playback and removal experiments. Animal Behaviour 30:171181.

Rice, J. 1978. Behavioral interactions of interspecifically territorial vireos. I. Song discrimination and natural interactions. Animal Behaviour 26:527-549.

Rice, W. R. 1989. Analyzing tables of statistical tests. Evolution 43:223-225.

Robinson, S. K., and J. Terborgh. 1995. Interspecific aggression and habitat selection by Amazonian birds. Journal of Animal Ecology 64:1-11.

SPSS. 1997. Base 7.5 for Windows. SPSS, Inc., Chicago, Illinois, USA.

Stein, R. C. 1958. The behavioral, ecological and morphological characteristics of two populations of the Alder Flycatcher, Empidonax traillii (Audubon). New York State Museum Bulletin 371:1-63.

Szijj, L. J. 1962. A comparative study of the sympatric species of meadowlarks (genus Sturnella) in Ontario. Dissertation, University of Toronto, Toronto, Ontario, Canada. 